\title{
Arthrodiastasis for stiff hips in young patients
}

\author{
J. Cañadell, F. Gonzales, R. H. Barrios, and S. Amillo
}

Department of Orthopaedic Surgery and Traumatology, University Clinic, School of Medicine, University of Navarra, Pamplona, Spain

Reprint requests to: S. Amillo MD

Department of Orthopaedic Surgery

Clínica Universidad de Navarra

Avda. Pío XII s/n, Pamplona, Spain

\section{SUMMARY}

Joint distraction (arthrodiastasis) with a unilateral fixator was used to treat 9 patients with stiffness of the hip which had followed Perthes' disease (3), epiphysiolysis (2), congenital dysplasia (2), tuberculosis (1) and idiopathic chondrolysis (1). Their average age was 14 years, and they all had pain, limp and shortening of the leg. Distraction of 0.5 to $1 \mathrm{~cm}$ was maintained for an average of 94 days. The average range of movement subsequently was $65^{\circ}$ compared with $20^{\circ}$ before. The articular space was widened by an average of $2.8 \mathrm{~mm}$, and only 3 patients had pain on follow up.

\section{RÉSUMÉ}

Les auteurs rapportent leur expérience du traitement des raideurs de la hanche par la technique de distraction articulaire: "arthrodiastasis". Ils en ont 9 cas, 3 séquelles de Legg-Perthes-Calvé, 2 épiphysiolyses, 2 dysplasies congénitales, une tuberculose et une chondrolyse idiopathique, avec un recul moyen de 39 mois (de 13 à 69 mois). L'âge moyen des patients était de 14 ans (de 12 à 21 ans). Tous présentaient des douleurs, une claudication, un raccourcissement (de $28 \mathrm{~mm}$ en moyenne), ainsi qu'une attitude vicieuse en flexion ( $52^{\circ}$ en moyenne) et adduction $\left(26^{\circ}\right.$ en moyenne). Nous avons utilisé un fixateur externe unilatéral et maintenu une distraction de $0.5-1.0 \mathrm{~cm}$ pendant une durée moyenne de 94 jours (de 35 à 210 jours). Le résultat final a été évalué cliniquement et d'après l'évolution radiologique. La mobilité était de $20^{\circ}$ en moyenne en pré-opératoire et de $65^{\circ}$ après la chirurgie. En fin d'évolution on a constaté un élargissement de $2.8 \mathrm{~mm}$ de l'interligne articulaire (de 1 à 4). La douleur persistait dans trois cas. Cette technique permet de rendre à une hanche raide so mobilité physiologique, elle stabilise les extrémités osseuses l'une par rapport à l'autre et maintient, lors de la mobilisation, un espace constant entre les éléments articulaires, ce qui évite les contacts osseux douloureux et permet la formation d'un tissu cicatriciel d'interposition destiné à devenir un tissue de support et de glissement. 


\section{INTRODUCTION}

Restoring movement to a stiff joint with degenerative changes will make it stable and painless. In young patients, the alternative to a total hip replacement is arthrodesis which relieves pain and stabilises the joint $[2,8]$, but the loss of movement results in overloading of the lumbar spine and knee producing problems in the future $[2,5,8,10]$. Arthroplasty with interposition of human tissue and joint distraction (arthrodiastasis) are other solutions [6].

Mobilisation of a joint while its surfaces are distracted by an external fixator was described in 1975 [11]. This method allows alignment of the articular surfaces and diminishes pressure from dynamic and static loads [3, 4, 6]. Articular friction is diminished, abnormal movement prevented and contractures eliminated. This paper describes the technique of arthrodiastasis and the results we obtained.

\section{MATERIAL AND METHOD}

Between 1984 and 1989, 9 patients were treated by arthrodiastasis of the hip. The stiffness was a sequel to Perthes' disease in 3, epiphysiolysis in 2, congenital dysplasia in 2, tuberculosis in 1 and idiopathic chondrolysis in 1 (Table 1). There were 5 males and 4 females with an average age of 14 years (range 12 to 21 years). The average period of evolution of symptoms was 77 months (range 4 to 168 months). Two patients had previously had a derotation-valgus osteotomy, and 2 had had adductor tenotomies. One patient with epiphysiolysis had been treated elsewhere by internal fixation with Kirschner wires. One other patient others had a Chiari osteotomy.

Every patient had pain and stiffness with a limp, and the average leg length discrepancy was $28 \mathrm{~mm}$ (range 10 to $50 \mathrm{~mm}$ ) (Table 1). We used a unilateral external fixator (Orthofix) that has a hinge which allows flexion and extension at the hip [4]. It was set so that the hinge was over the centre of rotation of the femoral head (Fig. 1) and was maintained for an average period of 94 days (range 35 to 210 days).

The procedure was carried out under anaesthesia with the patient supine. Two Schanz pins were inserted into the iliac wing or in the supra-acetabular region, and two into the femoral shaft (Fig. 1). Immediate distraction of 0.5 to $1 \mathrm{~cm}$ was carried out. An adductor tenotomy was done at the same time in 2 patients. The fixator was kept locked posteriorly for 10 days, and then progressive nonweightbearing mobilisation was allowed for about 3 months, after which the fixator was removed. This was followed by a daily rehabilitation programme with passive continuous and active assisted movement, and hydrotherapy. Progressive weightbearing continued for 3 months and full weightbearing was begun 6 months after operation. Three patients used a Thomas calliper, while the others preferred crutches.

The patients were followed and records made of the range of movement. Anteroposterior and axial radiographs were taken during the operation, 15 days tater and then each month. The articular space was measured and compared with the preoperative radiograph (Table 2). The method of assessing pain is shown in Table 3. The average follow up was 39 months (range 13 to 69 months). 


\section{RESULTS}

The average range of movement before operation was $20^{\circ}$ (range 0 to $60^{\circ}$ ); 3 patients had an ankylosed hip. There was an average flexion contracture of $52^{\circ}$ (range $20^{\circ}$ to $80^{\circ}$ ) and an average adduction contracture of $6^{\circ}$ (Table 1). At the end of the period of follow up, the average arc of flexion-extension was $65^{\circ}$ (range 0 to $100^{\circ}$ ) (Fig. 2).

Radiographic evaluation showed an average increase of $2.8 \mathrm{~mm}$ in the articular space, with a preoperative average of $1.3 \mathrm{~mm}$ and postoperatively $4.1 \mathrm{~mm}$ (Table 2; Figs. 3, 4, $5)$.

Five patients had severe pain before operation, 3 moderate pain and one mild pain. At follow up, 3 patients still had pain. One (case 8) had 2 manipulations under anaesthesia after arthrodiastasis, but was not able to undergo physiotherapy because of pain. There was no improvement in either movement or pain and an arthrodesis was carried out $2^{1 / 2}$ years later. The other 2 patients, who had severe pain before, had only occasional pain postoperatively.

Another patient (case 9) fell 2 months after the fixator had been removed and sustained a supracondylar fracture of the femur. This event contributed to continuing stiffness of the hip.

The pins became loose in 2 patients. In one they had to be changed; this was the patient who had the best range of movement during arthrodiastasis. One patient had infection around the distal pins and the external fixator had to be removed; the infection then resolved with local antiseptics and oral antibiotics. In one patient a collateral branch of the gluteal artery was damaged by the pins and a further operation was needed to coagulate the vessel.

\section{DISCUSSION}

We used arthrodiastasis to postpone the need for total hip replacement, and consider it to be indicated in healthy young patients with painful stiffness or ankylosis and contractures.

The hinged Orthofix ${ }^{\mathrm{R}}$ fixator is appropriate because it allows flexion and extension while distraction is maintained. Our results were good, especially with regard to improvement in pain and movement. Stiffness secondary to various causes can thus be mobilised without arthroplasty, and decreased pain has been reported by many authors $[6,7,9,11]$. Arthrodiastasis has therefore been proposed as an alternative method of treatment of articular stiffness of the hip [1]. Complications are few and can be prevented by careful placement of the Schanz pins.

The hinge of the external fixator must be over the centre of rotation of the femoral head. If this is not done movement will be painful, improvement will be limited and loosening of the pins is more likely.

A decision must be made about the need for tenotomy when there is an adduction deformity. We do not consider it necessary to interpose any material in the joint. 
Once flexion-extension movements are allowed, it is important to insist that they are repeated regularly. After removal of the external fixator a regular programme of rehabilitation must be carried out to regain a useful range of movement. Nonweightbearing must be prolonged sufficiently to allow a new osteocartilaginous articular surface to be formed, and this takes about 6 months.

The fixator must be maintained until radiographs have shown a constant measurement of the articular space for at least a month, but there is always a decrease compared with the space seen immediately after distraction.

We believe that our good results were obtained because of the formation of fibrous tissue in the joint which acts as a slippery surface; pain is avoided and stability secured.

\section{REFERENCES}

1. Aldegheri R, Agostini S, Renzi Brivio L (1982) Artrodiatasi d'anca (esperienza clinica). Chir Organi Mov 68: 527-531

2. Alvik I (1963) Arthrodesis and arthroplasty of the hip joint. Acta Orthop Scand 33: 253

3. Deland JT, Garg A, Walker PS (1987) Biomechanical basis for elbow hingedistractor design. Clin Orthop 215: 303-312

4. De Bastiani G, Aldegheri R, Renzi Brivio L (1984) The treatment of fractures with dynamic axial fixator. J Bone Joint Surg [Br] 66: 538-545

5. Greiss MD, Thomas RJ, Freeman MA (1980) Sequelae of arthrodesis of the hip. J R Soc Med 73: 497

6. Judet R, Judet T (1978) Arthrolyse et arthroplastie sous distracteur articulaire. Rev Chir Orthop 64: 353-365

7. Lance D, Carlioz A, Seringe R, Postel M, Lacombe MJ, Abelanet R (1981) La chondrolyse ou coxite laminaire juvénile après épiphysiolyse fémorale supérieure. Etude clinique et thérapeutique à propos de 41 observations. Rev Chir Orthop 67: 437-450

8. Merle D'Aubigné R, Ramadier JO, Postel M, Mazas F, Vaillant JM (1964) L'Arthrodèse de la hanche. Rev Chir Orthop 50: 789-812

9. Morrey F (1990) Post-traumatic contracture of the elbow. Operative treatment, including distraction arthroplasty. J Bone Joint Surg [Am] 72: 601-618

10. Sponseller PD, McBeath AA, Perpich MM (1984) Hip arthrodesis in young patients. J Bone Joint Surg [Am] 66: 853-859

11. Volkov MV, Oganesian OV (1975) Restoration of function in the knee and elbow with a hinge-distractor apparatus. J Bone Joint Surg [Am] 57: 591-600 


\begin{tabular}{|c|c|c|c|c|c|c|c|c|c|c|c|c|c|c|c|}
\hline \multirow{2}{*}{ Case } & \multirow{2}{*}{$\begin{array}{l}\text { Sex/ } \\
\text { age }\end{array}$} & \multirow{2}{*}{\multicolumn{2}{|c|}{ Side diagnosis }} & \multirow{2}{*}{$\begin{array}{c}\text { Previous or } \\
\text { associated } \\
\text { treatment }\end{array}$} & \multirow{2}{*}{$\begin{array}{l}\text { Duration } \\
\text { symptoms } \\
\text { (months) }\end{array}$} & \multirow{2}{*}{$\begin{array}{l}\text { Pain } \\
\text { pre/ } \\
\text { post }\end{array}$} & \multicolumn{3}{|c|}{ Motion pre/post } & \multirow[b]{2}{*}{ ER } & \multirow[b]{2}{*}{$\mathbf{A B}$} & \multirow[b]{2}{*}{ AD } & \multirow{2}{*}{$\begin{array}{l}\text { Time with } \\
\text { fixator } \\
\text { (days) }\end{array}$} & \multirow{2}{*}{$\begin{array}{l}\text { Follow-up } \\
\text { (months) }\end{array}$} & \multirow{2}{*}{ Complications } \\
\hline & & & & & & & FL & EX & $\mathbf{I R}$ & & & & & & \\
\hline \multirow[t]{2}{*}{ I } & F/I3 & $\mathrm{L}$ & $\mathrm{CDH}$ & \begin{tabular}{|c|}
$\begin{array}{c}\text { Femoral } \\
\text { osteotomy }\end{array}$ \\
\end{tabular} & 156 & $3 / 0$ & $90 / 90$ & $-50 / 0$ & $0 / 10$ & $0 / 10$ & $20 / 20$ & $10 / 10$ & 210 & 69 & Pin loosening \\
\hline & & & & $\begin{array}{l}\text { Adductor } \\
\text { tenotomy }\end{array}$ & & & & & & & & & & & \\
\hline 2 & $F / 21$ & $\mathrm{~L}$ & Perthes & $\begin{array}{l}\text { Adductor } \\
\text { tenotomy }\end{array}$ & 108 & $3 / 1$ & $90 / 60$ & $-60 /-10$ & $0 / 5$ & $0 / 5$ & $0 / 10$ & $0 / 10$ & 90 & 28 & \\
\hline 3 & $\mathrm{M} / 17$ & $\mathrm{R}$ & Epiphysiolysis & K-wires & 24 & $1 / 0$ & $50 / 80$ & $-50 / 0$ & $-15 / 0$ & $15 / 0$ & $-40 / 20$ & $40 / 20$ & 90 & 21 & $\begin{array}{c}\text { Gluteal artery } \\
\text { lesion }\end{array}$ \\
\hline 4 & $\mathrm{~F} / 13$ & $\mathrm{R}$ & Perthes & \begin{tabular}{c|} 
Femoral \\
osteotomy
\end{tabular} & 36 & $3 / 0$ & $45 / 70$ & $\mid-45 /-10$ & $0 / 0$ & $0 / 0$ & $-25 / 30$ & $25 / 10$ & 35 & 38 & \\
\hline 5 & $\mathrm{M} / 14$ & $\mathrm{~L}$ & $\mathrm{TBC}$ & Medical & 108 & $2 / 0$ & $60 / 100$ & $-45 / 0$ & $0 / 20$ & $0 / 10$ & $0 / 10$ & $0 / 10$ & 50 & 44 & Pin loosening \\
\hline 6 & $\mathrm{M} / 12$ & $\mathrm{~L}$ & Perthes & $\begin{array}{l}\text { Adductor } \\
\text { tenotomy }\end{array}$ & 4 & $3 / 0$ & $80 / 90$ & $-20 / 0$ & $0 / 0$ & $0 / 0$ & $-25 / 20$ & $25 / 15$ & 90 & 22 & \\
\hline 7 & $\mathrm{~F} / 15$ & $\mathrm{~L}$ & $\mathrm{CDH}$ & $\begin{array}{c}\text { Chiari' s } \\
\text { osteotomy }\end{array}$ & 168 & $3 / 0$ & $10 / 90$ & $-80 / 0$ & $0 / 15$ & $0 / 0$ & $10 / 30$ & $20 / 20$ & 130 & 27 & \\
\hline 8 & $\mathrm{M} / 13$ & $\mathrm{~L}$ & Epiphysiolysis & & 7 & $2 / 3$ & $70 / 50$ & $\mid-70 /-50$ & $0 / 0$ & $0 / 0$ & $-25 /-20$ & $25 / 20$ & 78 & 44 & Pin infection \\
\hline 9 & $\mathrm{M} / 12$ & $\mathrm{R}$ & Chondrolysis & Traction & 35 & $2 / 1$ & $75 / 45$ & $\mid-50 /-20$ & $0 / 0$ & $0 / 0$ & $-15 / 0$ & $15 / 0$ & 75 & 13 & \\
\hline
\end{tabular}

\begin{tabular}{|c|c|c|c|}
\hline \multicolumn{4}{|c|}{ Table 2. Articular space } \\
\hline & \multicolumn{3}{|c|}{ Distance (mm) } \\
\hline Case & Pre & Intra & Post \\
\hline 1 & 0 & 10 & 4 \\
\hline 2 & 0 & 4 & 2 \\
\hline 3 & 2 & 8 & 5 \\
\hline 4 & 1 & 6 & 4 \\
\hline 5 & 1 & 8 & 5 \\
\hline 6 & 4 & 6 & 8 \\
\hline 7 & 1 & 5 & 4 \\
\hline 8 & 1 & 4 & 3 \\
\hline 9 & 2 & 6 & 3 \\
\hline$X$ & 1,33 & 6,33 & 4,22 \\
\hline
\end{tabular}

Table 3. Pain evaluation

\begin{tabular}{|c|c|}
\hline 0 & No pain \\
\hline 1 & Mild or occasional, no analgesics \\
\hline 2 & Moderate, night pain, occasional need of analgesics, no limitation for daily activities \\
\hline 3 & Severe, frequent need of analgesics, limitation in daily activities \\
\hline
\end{tabular}




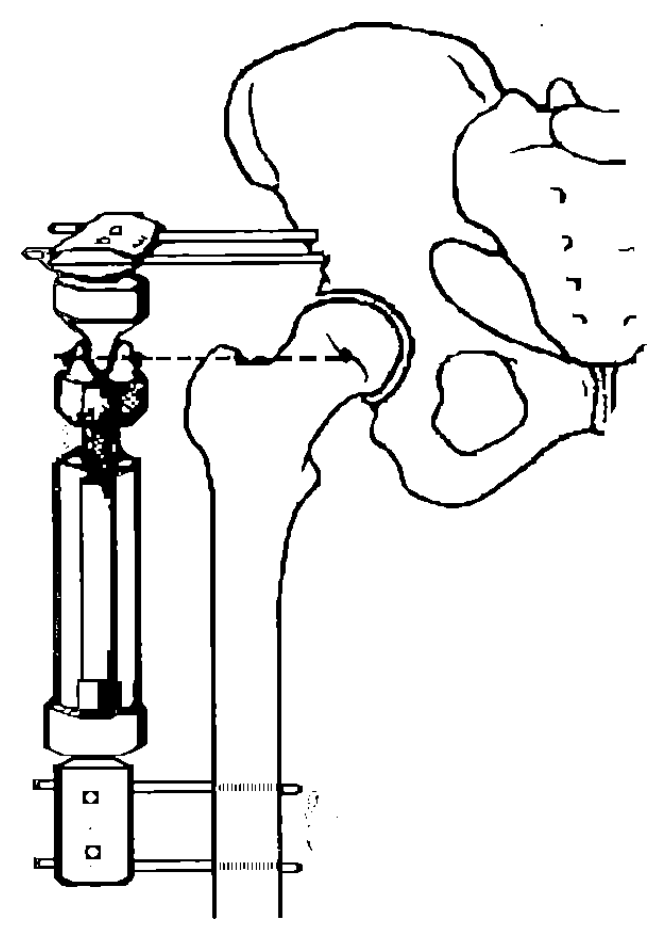

Figure 1. Diagram showing the technique of arthrodiastasis. The centre of rotation of the femoral head coincides with the hinge of the external fixator.

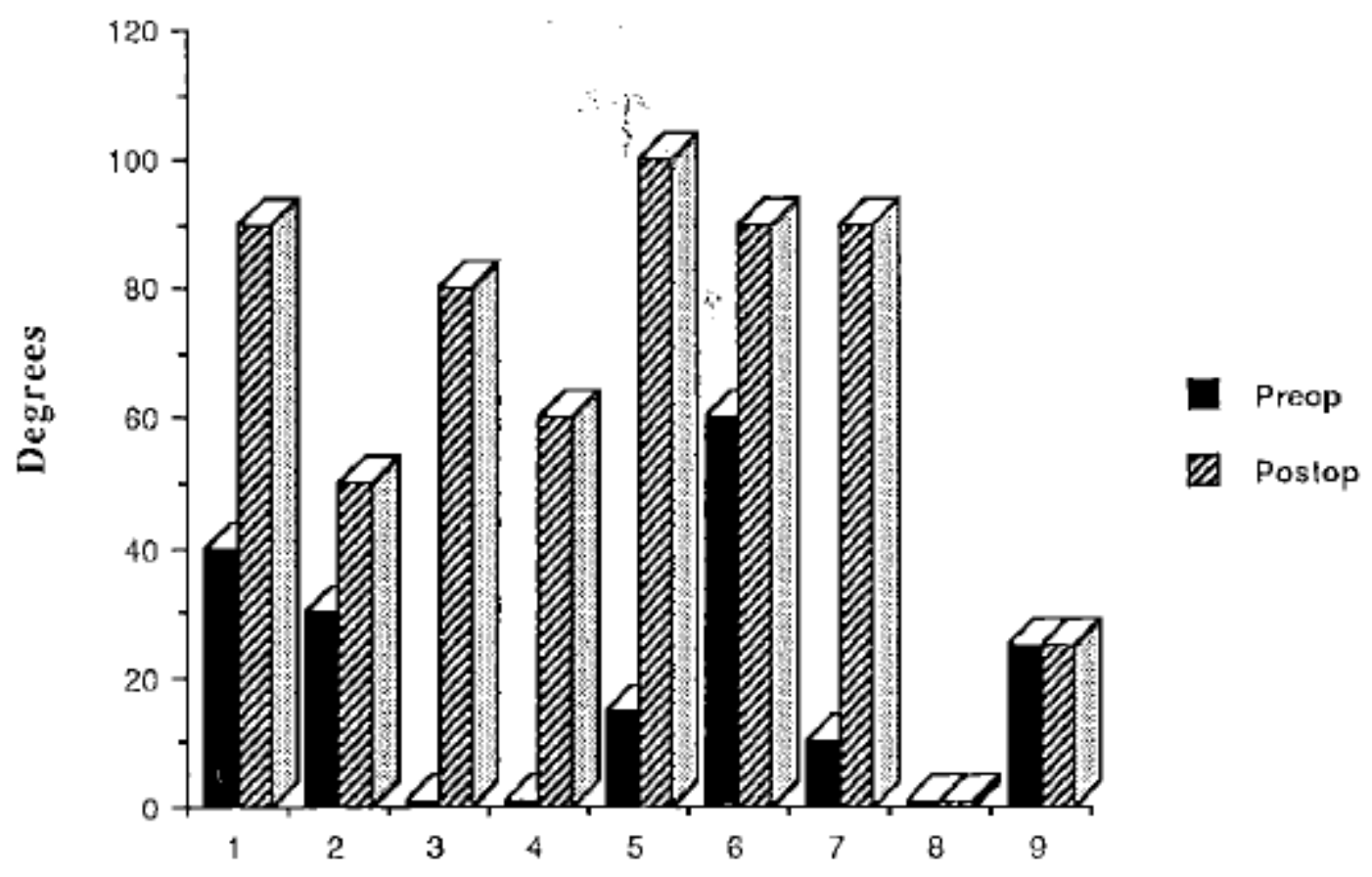

Patients

Figure 2. Histogram showing range of movement before and after operation. 

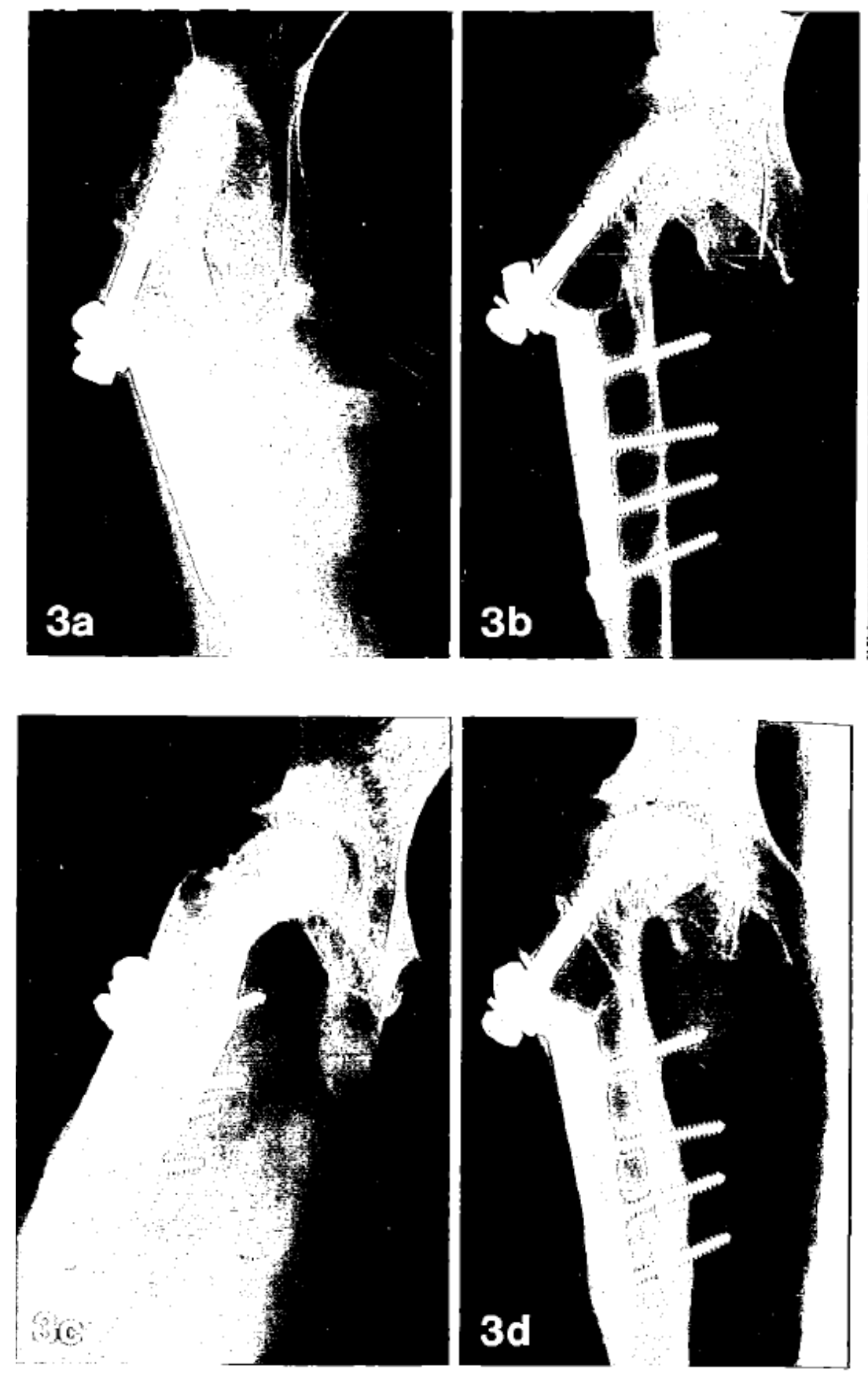

Figure 3a-d. Case 1. A patient aged 13 years with congenital dysplasia who had a valgus osteotomy previously. a Radiograph after distraction. b Increase in articular space during arthrodiastasis. c, d Axial and anteroposterior views 57 months after operation. 

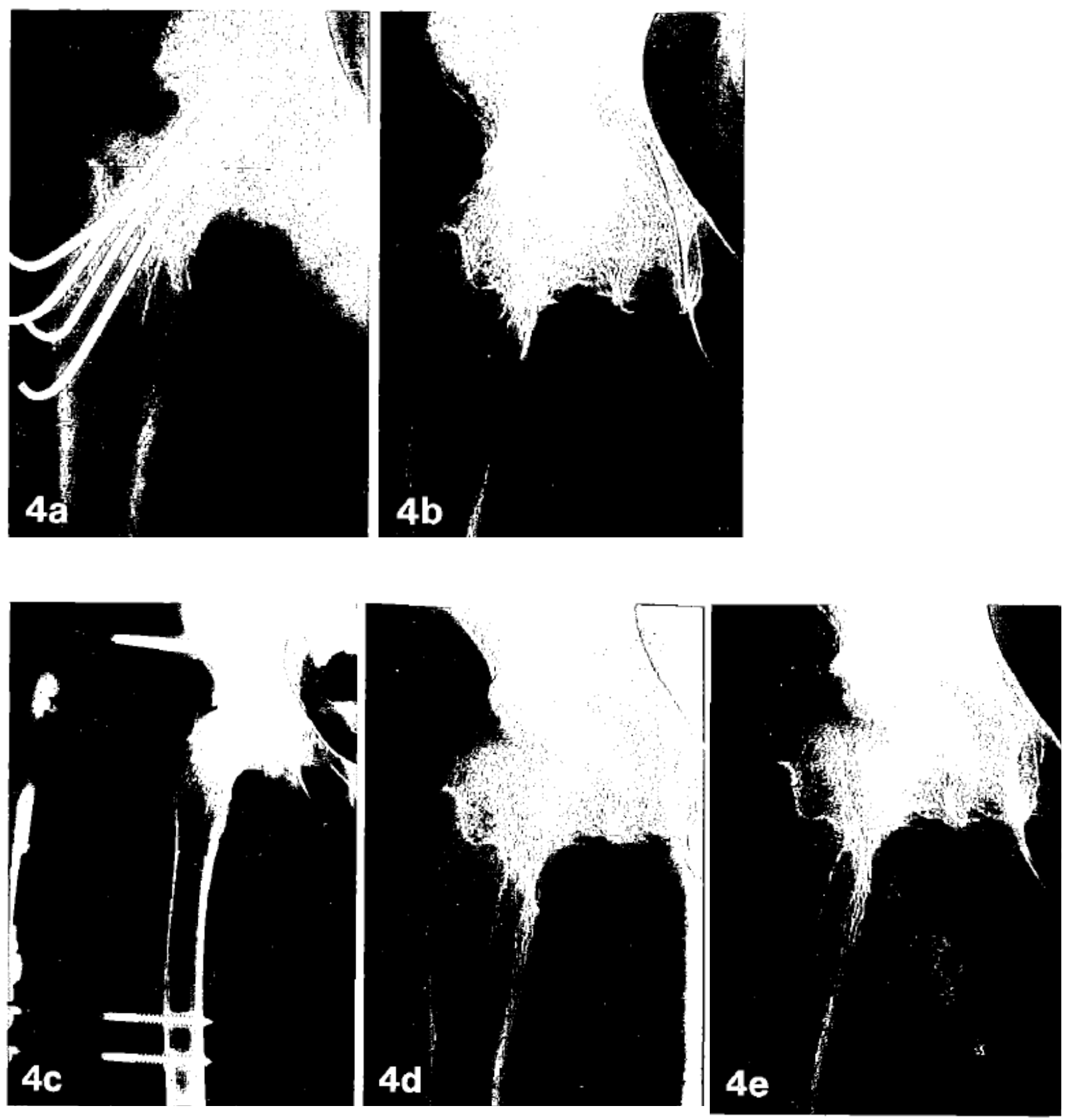

Figure 4a-e. Case 3. A patient aged 17 years with epiphysiolysis of the hip. a After insertion of Kirschner wires in an another hospital. b Decrease in articular space and chondrolysis. $\mathbf{c}$ The external fixator in position and immediate distraction. d Radiograph showing the articular space achieved. e 18 months after operation. 


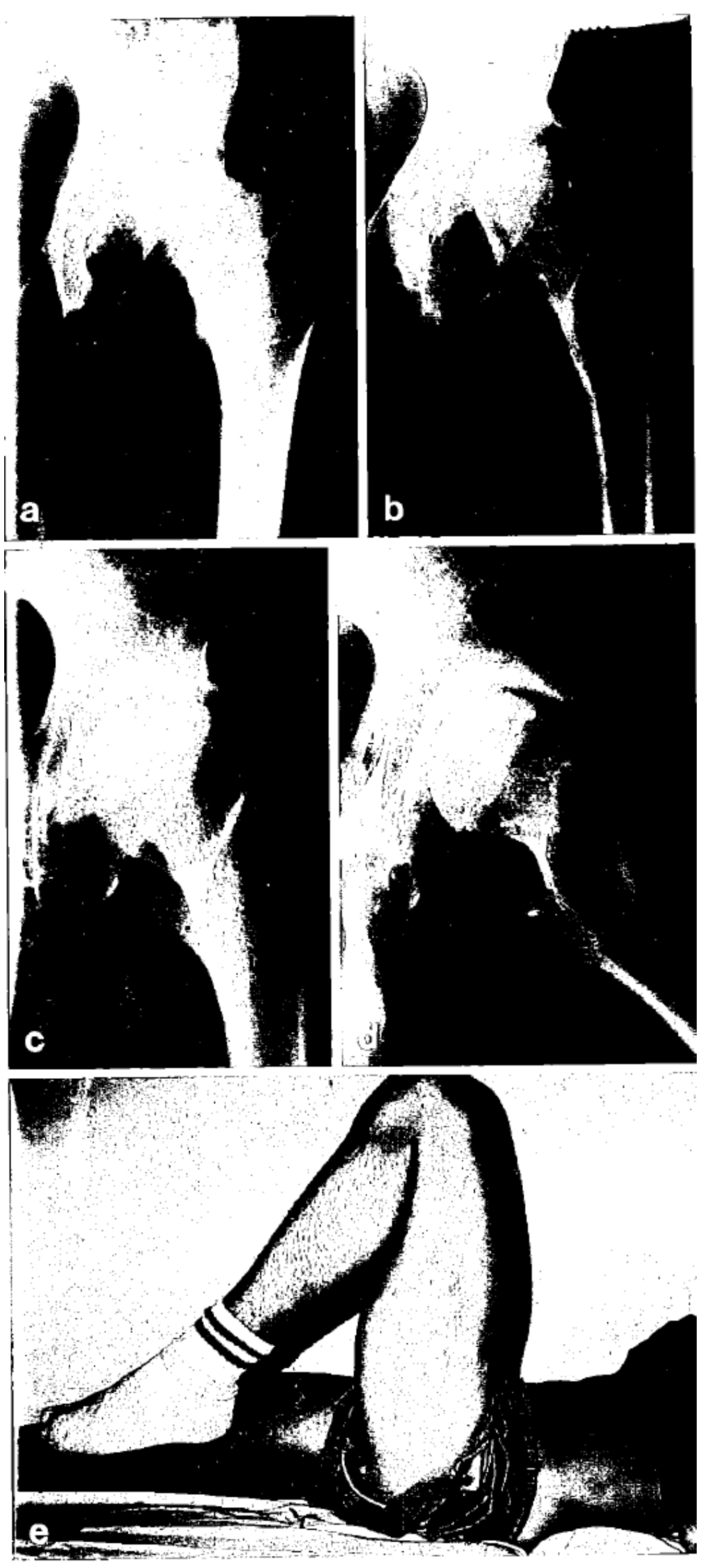

Figure 5a-e. Case 5. A patient aged 14 years with sequelae of tuberculous arthritis. a Radiograph before operation. b During distraction. c, d Axial and anteroposterior views 30 months after operation. e Photograph showing hip flexion 30 months after operation. 